\title{
Does Length of Waiting Time in the Emergency Room Affect Patient Satisfaction?
}

\author{
Ria Rizki Kusumasari *, Sri Sundari ${ }^{* *}$ \\ DOI: 10.29322/IJSRP.11.08.2021.p11650 \\ http://dx.doi.org/10.29322/IJSRP.11.08.2021.p11650
}

${ }^{*}$ Hospital Administration Management Study Program, University of Muhammadiyah Yogyakarta, Yogyakarta, Indonesia

** Hospital Administration Management Study Program, University of Muhammadiyah Yogyakarta, Yogyakarta, Indonesia

\begin{abstract}
Background: Patient satisfaction is an important goal in the health care system and the length of waiting time is a sensitive matter because it can cause a decrease in the quality of health services in hospitals. The purpose of this study was to determine the effect and causes of length of waiting time of patients in the Emergency Room. Subjects and Methods: This research method is a mixed method with an exploratory sequential approach. The data was collected through interviews and surveys using questionnaires, patient internal transfer sheets, and handover sheets for inpatients. The analysis of the data used content analysis method and SPSS software. Results: The length of waiting time in the Emergency Room has a significant effect on patient satisfaction (sig. $0.000<0.05$ ). The length of waiting time in the Emergency Room Influenced by the lack of socialization of SOPs related to the length of time elapsed from the emergency room to the inpatient room, the lack of emergency room nurses, no patient pusher staff, manual laboratory equipment used, on-call radiology officers, registration counter for inpatient and outpatient services that have not been separated, the use of the bed management system is not optimal, the inpatient nurse delays to verbed the room because of other duties and the inpatient room nurse is not available Conclusion: The sooner the patient leaves the emergency room, the more satisfied the patient will be.
\end{abstract}

Index Terms- About four key words or phrases in alphabetical order, separated by commas. Keywords are used to retrieve documents in an information system such as an online journal or a search engine. (Mention 4-5 keywords)

\section{INTRODUCTION}

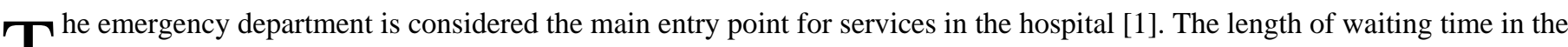

Emergency Room is a sensitive matter because it can cause a decrease in the quality of health services in hospitals. Patients will assume that health services are bad if the illness does not heal quickly, the waiting time is long, and the health workers are not friendly even though they are professional [2]. The length of waiting time in the Emergency Room is the most important part of patient satisfaction, starting from an explanation of laboratory tests and results, the patient's condition, and the reason for entering the patient which has a major impact on the level of patient satisfaction [3]. Patient satisfaction is an important goal in the health care system. Many factors affect patient satisfaction related to health services and health care providers. [3] According to [4] the factors that influence satisfaction include: discrepancy with the expectations and reality experienced by patients, ranging from the behavior of health care providers, quality of health services, atmosphere and physical conditions of the environment, prices, and promotions or advertisements.

Patient satisfaction is a metric used to measure the effectiveness of patient-centred health services [5] As mentioned in the research by [6] patients who waited a long time in the Emergency Room had lower patient satisfaction scores. In addition, the highest patient satisfaction within 30 to 40 minutes of total waiting time in the Emergency Room was also mentioned in the research of [7]; [8]. Therefore, researchers in this study will look for the effects and causes of long waiting times in the Emergency Room so that they can provide a solution to shorten the length of time in the Emergency Room so that patients are always satisfied with the services provided.

\section{RESEARCH METHOD}

This study is a mixed method study with a sequential exploratory approach with a sample of 10 informants, namely all officers in the ER and 92 respondents, namely inpatients who are included in priority 2. Data collection is carried out by interviews and surveys using questionnaires and patient internal transfer sheets and sheets handover of inpatients. This research method is content analysis method and SPSS software. The variables used in this study were the length of waiting time in the Emergency Room and the level of patient satisfaction. Patient satisfaction which has dimensions of satisfaction with physical facilities, satisfaction with staff performance, satisfaction with technical and medical services, satisfaction with costs [9].

\section{WRITE DOWN YOUR STUDIES AND FINDINGS}


Table 1. Characteristics of research informants

\begin{tabular}{|l|l|l|l|}
\hline \multirow{2}{*}{ Category } & \multirow{2}{*}{ Characteristic } & \multicolumn{2}{|c|}{ Frequency } \\
\cline { 3 - 4 } & & N & \% \\
\hline Sex & Man & 6 & $60 \%$ \\
& Woman & 4 & $40 \%$ \\
\hline Age & $25-34$ y.o & 9 & $90 \%$ \\
& $35-39$ y.o & 1 & $10 \%$ \\
\hline Education & D-III & 8 & $80 \%$ \\
& S1 & 2 & $20 \%$ \\
\hline Lenght of employement & $<5$ years & 7 & $70 \%$ \\
& $\geq 5$ years & 3 & $30 \%$ \\
\hline
\end{tabular}

The results in table 1 show that the majority of the informants in this study were male, as many as 6 informants (60\%), aged 25-34 years as many as 9 informants (90\%), having the last education D III as many as 8 informants (80\%), and have worked in the hospital for $<5$ years as many as 7 informants $(70 \%)$.

Table 2. Characteristics of research respondents

\begin{tabular}{|c|c|c|c|}
\hline \multirow{2}{*}{ Category } & \multirow{2}{*}{ Characteristic } & \multicolumn{2}{|l|}{ Frequency } \\
\hline & & $\mathbf{N}$ & $\%$ \\
\hline \multirow[t]{2}{*}{ Sex } & Man & 44 & $47,83 \%$ \\
\hline & Woman & 48 & $52,17 \%$ \\
\hline \multirow[t]{5}{*}{ Age } & $<20$ y.o & 10 & $10,87 \%$ \\
\hline & $20-30$ y.o & 15 & $16,30 \%$ \\
\hline & $31-40$ у.о & 30 & $32,61 \%$ \\
\hline & $41-50$ у.о & 12 & $13,05 \%$ \\
\hline & $>50$ y.o & 25 & $27,17 \%$ \\
\hline \multirow[t]{5}{*}{ Education } & Elementary & 22 & $23,92 \%$ \\
\hline & Junior High & 15 & $16,30 \%$ \\
\hline & Senior High & 48 & $52,17 \%$ \\
\hline & Diploma & 3 & $3,26 \%$ \\
\hline & $\mathrm{S} 1 / \mathrm{S} 2 / \mathrm{S} 3$ & 4 & $4,35 \%$ \\
\hline \multirow[t]{5}{*}{ Occupation } & PNS & 1 & $1,09 \%$ \\
\hline & TNI / POLRI & 0 & $0 \%$ \\
\hline & Private Employees & 31 & $33,69 \%$ \\
\hline & Self-employed Student / College student & 50 & $54,35 \%$ \\
\hline & & 10 & $10,87 \%$ \\
\hline \multirow[t]{5}{*}{ Montly Income } & Rp 1 million & 40 & $43,48 \%$ \\
\hline & Rp 1 million - Rp 2 million & 48 & $52,17 \%$ \\
\hline & Rp 2 million - Rp 5 million & 3 & $3,26 \%$ \\
\hline & Rp 5 million - Rp 10 million & 1 & $1,09 \%$ \\
\hline & Rp 10 million & 0 & $0 \%$ \\
\hline
\end{tabular}

The research instrument used was a questionnaire. [10] conducted a validity test and questionnaire reliability test. The validity test of the questionnaire using the product moment correlation technique, with a significant level of 5\%. The reliability test of the questionnaire was measured using the Cronbach coefficient . Other research instruments used are interview guidelines and tested using data validity tests, including: credibility (degree of trust), transferability (transferability), dependability (dependence), confirmability (certainty).

The descriptive analysis of the length of time a patient transfers from the emergency room to the inpatient room on the level of patient satisfaction in table 3 shows that the fastest time to transfer patients from the emergency room to the inpatient room is 120 minutes as many as 38 people (41.30\%), patients who were transferred within 180 - 240 minutes as many as 11 people (11.96\%) but patients who were transferred in the longest time were $>240$ minutes as many as 38 people $(41.30 \%)$.

Table 3. Descriptive length of time for patient transfer from the emergency room to the inpatient room

\begin{tabular}{|c|c|c|}
\hline Duration of waiting time (minutes) & \multicolumn{2}{|c|}{ Frequency } \\
\cline { 2 - 3 } & $\mathbf{N}$ & $\mathbf{\%}$ \\
\hline$>\mathbf{2 4 0}$ min & 27 & $29,35 \%$ \\
\hline $\mathbf{1 8 0}-\mathbf{2 4 0} \mathbf{m i n}$ & 11 & $11,96 \%$ \\
\hline $\mathbf{1 2 0}-\mathbf{1 8 0} \mathbf{~ m i n}$ & 16 & $17,39 \%$ \\
\hline
\end{tabular}


Table 4. Descriptive patient satisfaction level

\begin{tabular}{|l|c|c|}
\hline \multirow{2}{*}{ Patient Satisfaction Level } & Frequency & \multicolumn{2}{|l|}{} \\
\cline { 2 - 3 } & \multicolumn{2}{|c|}{$\mathbf{N}$} \\
\hline$<\mathbf{5 5 \%}$ & 3 & $3,26 \%$ \\
\hline $\mathbf{5 5 \% - 7 5 \%}$ & 62 & $67,39 \%$ \\
\hline $\mathbf{7 5 \% - 1 0 0 \%}$ & 27 & $29,35 \%$ \\
\hline
\end{tabular}

Table 4 shows that respondents have a low level of patient satisfaction $<55 \%$ as many as 3 people $(3,26 \%)$, a moderate level of satisfaction between $55 \%-75 \%$ as many as 62 people $(67,39 \%)$ and a high satisfaction level of $75 \%-100 \%$ as many as 27 people (29, $35 \%)$.

Table 5. The analysis result of patient waiting time in the emergency department on the level of patient satisfaction

\begin{tabular}{|c|c|c|c|c|c|}
\hline \multirow{2}{*}{ Model } & \multicolumn{2}{|c|}{ Unstandardized Coefficients } & $\begin{array}{c}\text { Standardized } \\
\text { Coefficients }\end{array}$ & \multirow{2}{*}{ t } & Sig \\
\cline { 2 - 6 } & B & Std. Error & Beta & & .000 \\
\hline (Constant) & 72.854 & 1.228 & & 59.334 & .000 \\
\hline Lengh of time & -.885 & .177 & -.466 & -4.997 & .000 \\
\hline
\end{tabular}

In table 5, the results of the significance of $0.000<0.05$ means that the length of time the patient from the emergency department has a positive effect on the level of patient satisfaction. In the testing of hypothesis using the one simple test (table 6), the results obtained a significance value of $0.000<0.05$, which means that the waiting time for patient transfer from the emergency room to the inpatient room has a significant effect on the level of patient satisfaction.

Table 6. Results of one sample test analysis

\begin{tabular}{|c|c|c|c|c|c|}
\hline & \multirow[t]{2}{*}{$\mathrm{t}$} & \multirow[t]{2}{*}{ df } & \multirow[t]{2}{*}{ Sig. (2-tailed) } & \multirow{2}{*}{$\begin{array}{c}\text { Mean } \\
\text { Difference }\end{array}$} & $\begin{array}{c}\text { 95\% Confidence Interval of the } \\
\text { Difference }\end{array}$ \\
\hline & & & & & Lower \\
\hline Patient satisfaction & 99.710 & 91 & .000 & 63.18478 & 61.9260 \\
\hline Length of waiting time & 11.117 & 91 & .000 & 322.63043 & 264.9854 \\
\hline
\end{tabular}

Based on the Kolmogorov-Smirnov non-parametric normality test, the results obtained a significance value of $0.258>0.05$, which means that the residual data spreads normally.

Table 7. Heteroscedasticity test results

\begin{tabular}{|l|l|l|l|l|l|}
\hline \multirow{2}{*}{ Model } & $\begin{array}{l}\text { Unstandardized } \\
\text { Coefficients }\end{array}$ & & $\begin{array}{l}\text { Standardized } \\
\text { Coefficients }\end{array}$ & \multirow{2}{*}{ t } & \multirow{2}{*}{ Sig. } \\
\cline { 2 - 5 } & $\mathbf{B}$ & Std. Error & Beta & .661 & .510 \\
\hline Lengh of time & 15.611 & 23.619 & & .372 & .711 \\
\hline
\end{tabular}

From the data in table 7 , it is found that the significance result is $0.711>0.05$, so it can be interpreted that the residual data does not occur heteroscedasticity.

Table 8. The results of the coefficient of determination (adjusted R2)

\begin{tabular}{|l|l|l|l|l|}
\hline Model & R & R Square & Adjusted R Square & Std. Error of the Estimate \\
\hline 1 & $.466^{\mathrm{a}}$ & .217 & .209 & 7.833 \\
\hline
\end{tabular}

In table 8 , the results of $\mathrm{R}$ square 0.271 are close to the value of 1 which means that the independent variable can provide all the information to predict the dependent variable or in other words, the long waiting time for patient transfer from the emergency room to the inpatient room greatly affects the level of patient satisfaction.

From the results of interviews with all informants in the ER where all nurses who work in the ER unit are the main informants and the head of the ER unit as a triangulation informant, it is known the root causes of the long waiting time for patient transfer from the ER 
to the inpatient ward, namely: Lack of SOP socialization related to length waiting time for transfer of patients from the emergency room to the inpatient room, the lack of emergency room nurses, no staff to encourage patients, the laboratory equipment used is still manual, radiology officers on call, registration counters for inpatients and outpatients that have not been separated, the use of the bed system management is not optimal, the inpatient nurse delays to verbed the room because of other tasks and the inpatient room nurse is not available. The results of the study show that the waiting time for patient transfer from the emergency room to the inpatient room greatly affects the level of patient satisfaction. This is also in accordance with the research of [6] where patients with long waiting times in the ER have lower patient satisfaction scores $(\mathrm{p}<0.001)$ and the factors that influence the length of waiting time [12] in their research include: limited resources, lack of coordination, long waiting for laboratory results, long time to determine disease diagnosis, too many emergency room patients, room readiness inpatients receive patients from the ER.

By looking at the results of the above analysis, suggestions for improvement and periodic evaluation of existing policies such as evaluation of SOPs, length of waiting time for patient transfer to inpatient rooms and evaluation of the quality and quantity of medical personnel in the emergency department, considering this greatly affects the quality of service and is expected to provide a solution to reduce the long waiting time for patient transfer to the inpatient room at Hidayah Boyolali Hospital.Now it is the time to articulate the research work with ideas gathered in above steps by adopting any of below suitable approaches:

\section{CONCLUSION}

Based on the results of the analysis that has been carried out, it can be concluded as follows that there is a very significant effect between the length of waiting time for patient transfer from the emergency room to the inpatient room on the level of patient satisfaction and the factors that influence the length of waiting time for patient transfer from the emergency room to the inpatient room at Hidayah Boyolali Hospital, including: lack of SOP socialization related to the length of time waiting for patient transfer from the emergency room to the inpatient room, lack of emergency room nurses, no officers to encourage patients, laboratory equipment used is still manual, radiology officers who are on call, registration counters for inpatients and outpatients that have not been separated, the use of the bed management system is not optimal, the inpatient nurse delays to verbed the room because of other tasks and the inpatient room nurse is not available. This study can provide several inputs that can be used as evaluation material regarding the length of waiting time for patient transfer to the inpatient room with patient satisfaction. For the Hidayah Boyolali hospital, it can be used as a suggestion for improvement and periodic evaluation of existing policies such as evaluation of SOPs, length of waiting time for patient transfer to inpatient rooms and evaluation of the quality and quantity of medical personnel in the emergency department considering this It is very influential on the quality of service and is expected to provide a solution to reduce the long waiting time for patient transfer to the inpatient room. For further research, for future research it is necessary to include other variables in order to be able to produce research with a wider scope, which can be applied in managing hospitals.

This study still has limitations that need to be considered for further research. Theose limitations include: In qualitative research, researchers feel that the results outlined in this study have not been obtained as a whole. The quality of interview data depends on the motivation and understanding of the informants to answer questions from researchers. The limitation of research using questionnaires is that sometimes the answers given by respondents do not show the real situation and depend on the seriousness of the respondents in answering the questionnaire. The results of this study can be applied at the Hidayah Boyolali hospital but it need further study if it will be applied in other hospitals. In this study, only 2 variables were used, namely the length of time waiting for patient transfer from the emergency room to the inpatient room and patient satisfaction. For further researchers, it is hoped that they can add new variables so that they can broaden scientific knowledge related to the quality of services in hospitals.

\section{REFERENCES}

[1] Zakerimoghadam, M., Sadeghi, S., Ghiyasvandian, S., Kazemnejad, A., 2016. The Effect of Trauma Intervention on the Satisfaction of Patients Admitted to the Emergency Department: A Clinical Trial Study. Iran. Red Crescent Med. J. 18. https://doi.org/10.5812/ircmj.26452

[2] Wijono D. 1999.Manajemen mutu pelayanan kesehatan. Surabaya: Airlangga

[3] Abo-Hamad, W., Arisha, A., 2013. Simulation-based framework to improve patient experience in an emergency department. Eur. J. Oper. Res. 224, $154-166$. https://doi.org/10.1016/j.ejor.2012.07.028

[4] Kotler, P., 2002. Manajemen Pemasaran, Edisi Millenium II, Penerbit Prenhalindo, Jakarta.

[5] Morgan, M., Salzman, J., LeFevere, R., Thomas, A., Isenberger, K., 2015. Demographic, Operational, and Healthcare Utilization Factors Associated with Emergency Department Patient Satisfaction. West. J. Emerg. Med. 16, 516-526. https://doi.org/10.5811/westjem.2015.4.25074

[6] Parker, B., Marco, C., 2014. Emergency Department Length of Stay: Accuracy of Patient Estimates. West. J. Emerg. Med. 15, 170-175. https://doi.org/10.5811/westjem.2013.9.15816

[7] Abolfotouh, M.A., Al-Assiri, M.H., Alshahrani, R.T., Almutairi, Z.M., Hijazi, R.A., Alaskar, A.S., 2017. Predictors of patient satisfaction in an emergency care centre in central Saudi Arabia: a prospective study. Emerg. Med. J. 34, 27-33. https://doi.org/10.1136/emermed-2015-204954

[8] Chaou, C.-H., Chiu, T.-F., Yen, A.M.-F., Ng, C.-J., Chen, H.-H., 2016. Analyzing Factors Affecting Emergency Department Length of Stay-Using a Competing Risk-accelerated Failure Time Model: Medicine (Baltimore) 95, e3263. https://doi.org/10.1097/MD.0000000000003263

[9] Sadeh, E., 2017. Interrelationships among quality enablers, service quality, patients' satisfaction and loyalty in hospitals. TQM J. 29, $101-117$. https://doi.org/10.1108/TQM-02-2015-0032

[10] Kurniana, 2008. Analisis Kepuasan Pasien Terhadap Pelayanan Rawat Inap di Rumah Sakit Husada Jakarta.Thesis.

[11] Astuti, Kustiyah E. (2012). Analisis kepuasan pasien rawat inap atas pelayanan Rumah Sakit Umum Kabupaten Sragen. GEMA 26(48), 1356-1371

This publication is licensed under Creative Commons Attribution CC BY.

http://dx.doi.org/10.29322/IJSRP.11.08.2021.p11650 
[12] Deviantony, F., Ahsan, A., Setyoadi, S., 2017. Analysis Of Factors Associated With Boarding Time In Yellow Zone Of Emergency Department At Dr.Iskak Tulungagung Hospital. NurseLine J. 2, 109. https://doi.org/10.19184/nlj.v2i2.5928

\section{AUTHORS}

First Author - Ria Rizki Kusumasari, , and email: dr.riarizki@gmail.com

Second Author - Sri Sundari, Hospital Administration Management Study Program,

University of Muhammadiyah Yogyakarta, Yogyakarta, Indonesia and email

sundari_purbo@yahoo.com.sg

Correspondence Author - Ria Rizki Kusumasari, email dr.riarizki@ gmail.com, contact number. Mobile No. +62 899-5005-536 